Advocating for

Children's Rights

Tess Prendergast, Betsy Diamant-Cohen, and Annette Y. Goldsmith

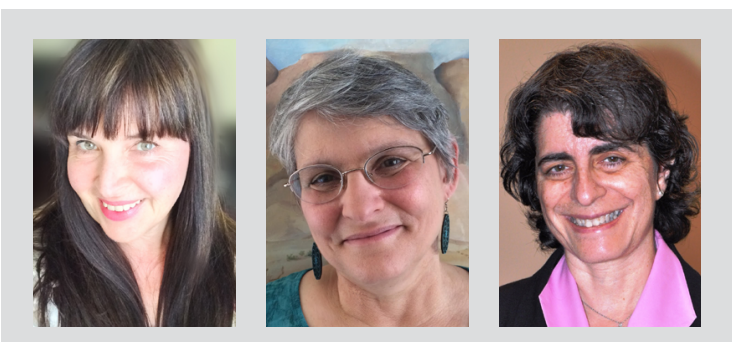

Tess Prendergast, PhD, is a Canadian children's librarian, researcher, and educator. Her most recent scholarly research explores early literacy in the lives of children with disabilities with a focus on the role of children's librarians. She works as a children's librarian in Vancouver, British Columbia, and teaches youth services courses at two post-secondary library education programs. Betsy Diamant-Cohen is an early literacy trainer and Executive Director of Mother Goose on the Loose, Baltimore. Annette Y. Goldsmith is a lecturer at the University of Washington Information School who teaches online from her home in Los Angeles.
A lthough the American Library Association and the Association for Library Service to Children are international organizations, meaning they welcome members from around the world, our scope tends to be North American in practice. While communities and funding structures in North American libraries are different (rural vs. urban for example), children's librarians often share similar outlooks on children and childhood in general.

However, while most ALSC members work within the cultural context of North American society, it is also important to understand the state of childhood on a more global scale. One way this can be accomplished is by taking a children's rights approach. The following annotated links (many shortened through TinyUrl.com) and print resources are meant as an introduction to children's rights for those working in public and school libraries around the world.

\section{Web Links}

\section{United Nations Convention on the Rights of the Child}

www.unicef.org/crc/

This is UNICEF's main page of links about children's rights and the United Nations Convention on the Rights of the Child. In addition to other human rights documents, this convention specifically and explicitly outlines the rights of children to "special care and attention" due to their vulnerability and dependence on adults for their well-being. It is important for all adults who work with children to see to the children's well-being through these enshrined rights and to determine ways to work towards ensuring all of their rights are protected no matter where they live in the world.

\section{The Convention on the Rights of the Child Cartoons}

https://tinyurl.com/unicef-crc-cartoons (on UNICEF site)

https://tinyurl.com/youtube-crc-cartoons (on YouTube)

This collection of thirty-two short animated films (each about thirty seconds long) presents visual interpretations of many of the Convention on the Rights of the Child articles. Teachers can use these videos as conversation starters about children's rights in their classrooms, while librarians may wish to use them to help incorporate children's rights themes into programming for school-age groups.

\section{Humanium}

www.humanium.org/en/

This is the English-language version of the international development organization called Humanium. Founded in Geneva in 2008, Humanium exists to help advance the cause of children's rights on a global scale. They sponsor children in specific countries who need support to meet their basic needs and to access education, among other development activities. The website includes a tab labeled "Situation in Countries" that informs readers about how children's rights are protected (or not) in countries around the world. Even rich countries have many areas of children's rights that need improvement. 
Malala Fund

www.malala.org/malalas-story

Nobel Peace Prize winner Malala Yousafzai is a young activist for girls' (and all children's) right to education. As a young teen, she was an outspoken activist for girls' education in Pakistan. At fifteen, she was shot in the head and critically injured on her school bus by the Taliban. She has emerged as one of the world's most resonant voices on girls' rights to education within the children's rights movement. Her story is inspirational and accessible to even very young children who will see a role model in Malala's story of hope and determination.

\section{Children's Human Rights: An Interdisciplinary Introduction}

https://tinyurl.com/children-s-rights-coursera

For those who wish to delve deeper into the topic, this is a free course about children's rights, delivered over Coursera. The topics include international standards and monitoring systems, the history of children's rights in the context of human rights, interdisciplinary children's rights studies, juvenile justice, violence against children, children's right to participation, and children's rights and global health. Students in library degree or diploma programs can use this resource to integrate knowledge gained into their assignments, group projects, and theses.

\section{Have the Right to Be a Child}

https://tinyurl.com/youtube-serres (book on YouTube) https://tinyurl.com/serres-discussion-guide (worksheet) https://groundwoodbooks.com/the-rights-of-the-child/ (Sheila Barry blog post)

The first link is a video version of Alain Serres's acclaimed 2012 book from Groundwood titled I Have the Right to Be a Child (translated into English from the French by Helen Mixter). The story is a reworking of some children's rights, told in the voice of a child, with riveting illustrations. This book should be included in all public and school library collections. The second link is to a worksheet produced by Phoenix Yard Books, designed to help upper primary and lower secondary school teachers and librarians use fiction to teach human rights. It includes information regarding the Convention on the Rights of the Child, questions for discussion, follow-up activities, and other useful resources.

The third link is a blog post from Sheila Barry, the late publisher of Groundwood, in which she ponders a world in which some children's rights to their own names are not yet a guarantee. She concludes with this beautiful statement that we think bears repeating for all of us working with children today.

So when I indulge in one of my frequent fantasies about how things would be different around this planet if I were supreme ruler of the universe, I don't stop at picturing all the world's children entering light-filled classrooms staffed by well-trained teachers who read to them every day no mat- ter how old they are. I also picture groups of children being given a copy of this book along with an assurance that the adults they encounter, both in school and outside, will work as hard as they can every day of their lives to deliver on the hopeful promises it contains. ${ }^{1}$

\section{Additional Resources}

\section{UN Convention on the Rights of the Child in Child Friendly Language}

www.unicef.org/rightsite/files/uncrcchilldfriendlylanguage .pdf (poster)

This colorful poster presents all of the articles of the convention in accessible, plain language directed at children to help them understand their rights. It would be a useful tool for classroom and program discussions with groups of children about their rights.

Celebrate National Child Day: Teaching about Children's Rights https://tinyurl.com/national-child-day

This is a great collection of other free online resources to help teach children about their rights. It includes links to information about the rights of indigenous youth and the rights of people with disabilities.

While Americans and Canadians may assume that our children's rights are already being protected due to our "rich country" status, examining children's rights further tells a different story. The United States has signed the Convention on the Rights of the Child but has yet to ratify the treaty-the only member of the United Nations that has not done so. ${ }^{2}$ And even though Canada has ratified the Convention, the rights of all Canadian children, particularly Indigenous children, are far from secure.

As children's library workers, our awareness of the movement to advance children's rights in the developing world can help our relatively privileged communities learn about global children's rights. Additionally, by learning about the state of children's rights in our own countries, we can also work towards ensuring that all children's rights are protected around the world. \&

\section{References}

1. Sheila Barry, "The Rights of the Child," Groundwood, May 21, 2013, https://www.groundwoodbooks.com /the-rights-of-the-child/.

2. Amy Rothschild, "Is America Holding Out on Protecting Children's Rights?” The Atlantic, May 2, 2017, https:// www.theatlantic.com/education/archive/2017/05 /holding-out-on-childrens-rights/524652/. 